\title{
Effective Teaching Strategies AND BehaViors of Legal Translation LECTURERS IN SPAIN
}

\author{
ESTRATEGIAS Y COMPORTAMIENTOS DIDÁCTICOS EFECTIVOS ENTRE PROFESORES \\ DE TRADUCCIÓN JURÍdICA EN ESPAÑa
STRATÉgies ET COMPORTEMENTS PÉdAg OgIQUES EFFICACES PARMi DE PROFESSEURS DE LA TRADUCTION JURIDIQUE EN ESPAgNe

\author{
Robert Martínez-Carrasco \\ Ph. D., in Applied Languages, \\ Literature \& Translation, Universitat \\ Jaume I, Spain. \\ Assistant Professor, Department of \\ Translation and Communications, Trans- \\ lation and Interpreting, Universitat \\ Jaume I, Spain. \\ rcarrasc@uji.es \\ https://orcid.
}

org/0000-0002-2148-8637

\begin{abstract}
Framed within the current accountability policies in higher education, under the strains of global competition and the internationalization of universities worldwide, this article examines effective teaching as a pillar of teaching quality in higher education among legal translation lecturers. By linking certain teaching and learning styles to the different dimensions of effective teaching (instructional, organizational, and emotional), the teaching profile of legal translation lecturers in Spain at undergraduate level is analyzed. In addition, student-centered teaching approaches are connected to the use of classroom strategies and methodological resources that characterize effective teaching. The findings of this study, obtained through the distribution of the TAMUFQ questionnaire (Teaching and Assessment Methodology of University Faculty Questionnaire) among legal translation lecturers at undergraduate level in Spain, suggest that those lecturers who adopt a post-positivist approach in their classroom display a greater variety of teaching behaviors and strategies associated with both effective curriculum implementation and higher quality teaching than those who are closer to traditional, positivist approaches. These findings may be particularly useful in the design and implementation of continuous professional development courses and pedagogical training of lecturers.
\end{abstract}

Keywords: legal translation; translation teaching; teaching strategies; higher education.

\section{RESUMEN}

Enmarcado en las políticas actuales de rendición de cuentas que caracterizan a la educación superior, bajo la presión de una mayor competencia global en lo que concierne a la internacionalización de las universidades, el presente artículo profundiza en el papel de la enseñanza efectiva como pilar de la calidad docente en la educación superior. Al vincular los diferentes estilos de enseñanza y aprendizaje a las dimensiones que caracterizan la enseñanza efectiva (instructiva, organizativa

Received: 2020-07-18 / Accepted: 2020-12-11 / Published: 2021-05-05

https://doi.org/10.17533/udea.ikala.v26n2a10 
y emocional), se analiza el perfil docente de los profesores de traducción jurídica de España a nivel de grado y se vinculan los enfoques docentes centrados en el alumno con el uso de determinadas estrategias y recursos metodológicos en el aula. Los resultados, obtenidos mediante la distribución del cuestionario TAMUFQ (Teaching and Assessment Methodology of University Faculty Questionnaire) entre el profesorado que imparte materias de traducción jurídica en España a nivel de grado, apuntan a que los docentes de traducción jurídica que adoptan perspectivas de corte pospositivista en el aula muestran una gama más amplia de comportamientos y estrategias docentes que han sido relacionadas con una implementación más efectiva del currículum y una docencia de mayor calidad. Estos hallazgos pueden ser especialmente útiles para el diseño y la implementación de programas de educación continua y para la formación pedagógica de los docentes.

Palabras clave: didáctica de la traducción; traducción jurídica; estrategias de enseñanza; educación superior.

\section{RÉSUMÉ}

Dans le cadre des politiques actuelles de responsabilité qui caractérisent l'enseignement supérieur, sous la pression d'une concurrence mondiale accrue concernant l'internationalisation des universités, cet article se penche sur le rôle d'un enseignement efficace en tant que pilier de la qualité de l'enseignement supérieur. En reliant les différents styles d'enseignement et d'apprentissage aux dimensions qui caractérisent un enseignement efficace (instructif, organisationnel et émotionnel), le profil d'enseignement des professeurs de traduction juridique en Espagne est analysé au niveau du premier cycle. Les approches pédagogiques axées sur l'étudiant sont reliées également à l'utilisation de certaines stratégies et ressources méthodologiques en classe. Les résultats, obtenus grâce à la distribution du questionnaire TAMUFQ (Teaching and Assessment Methodology of University Faculty Questionnaire) parmi les enseignants qui assurent des matières de traduction juridique en Espagne au niveau du premier cycle, suggèrent que les professeurs de traduction juridique qui adoptent des perspectives post-positivistes en classe font preuve d'un éventail plus large de comportements et de stratégies d'enseignement associés à une mise en œuvre plus efficace du programme et à un enseignement de meilleure qualité. Ces résultats peuvent être particulièrement utiles pour la conception et la mise en œuvre de programmes de formation continue et pour la formation pédagogique des enseignants.

Mots-clés : didactique de la traduction ; traduction juridique ; stratégies d'enseignement ; éducation du troisième cycle. 


\section{Introduction}

Access to university education has grown exponentially in the last hundred years, leading to the creation of new universities, faculties, and degrees across the globe in response to the growing social demand for higher education. This has resulted in a certain massification and commodification of higher education (De Courcy, 2015), which, in light of the current economic climate, has promoted the redefinition of the role of universities and lecturers. This redefinition has been heavily affected by global competition, internationalization, social migration, and a greater diversity in student profiles, not to mention cuts in funding structures, which have put even greater economic pressure on management departments at academic institutions.

With greater economic constraints and budgetary shortfalls than ever before, universities face various challenges: increasingly stringent processes of accreditation and auditing; pressure to appear in international rankings developed through the use of statistical indicators, such as the Academic Ranking of World Universities (ARWU), the Times Higher Education (THE), and the University Ranking by Academic Performance (URAP); processes of harmonization, such as those implemented in the European Higher Education Area (EHEA); as well as demands for more research of greater impact and more teaching, of higher quality.

In this climate, most of the responsibility to fulfill these requirements and reach the abovementioned standards ultimately falls on university lecturers. Lecturers must balance scholarship, teaching, and research in more adverse conditions than ever before (Gurung et al., 2018, p. 11), often with poorly implemented accountability structures, "increased workload, intensification of work, and a crisis of professional identity [due to] a loss of public confidence in their ability to provide a good service" (Day, 2012, p. 8). This, in part, is the result of neo-liberal policies and politics on education (Biesta, 2013; 2015), which seem to consider employability standards as the only indicators of success in higher education.

At the same time, the educational role of university lecturers has experienced a significant qualitative leap, at least within the EHEA, where student-centered learning environments have been promoted as part of a paradigm shift (Martínez-Carrasco, 2017, pp. 163-164) that has had direct repercussions on how "effective teaching is conceptualized, fostered and supported, evaluated, valuated and rewarded" (Saroyan \& Trigwell, 2015, p. 92). The pressure to demonstrate excellence in teaching within the EHEA continues to grow, with the problematic nature of defining "excellence" in the current scenario of constant change.

Relevant literature, in line with the gradual abandonment of the figure of the educator as the central element of education, has tended to show greater interest in learning styles and strategies rather than teaching styles, strategies, behaviors, and the impact of effective teaching on the student learning process (González-Peiteado \& Pino-Juste, 2016, p. 1186). Nevertheless, although it is widely accepted that the main focus of any educational environment should be the students, the sole implementer of the curriculum in the classroom is the lecturer (Dorgu, 2015, p. 78). Therefore, the teaching method and classroom methodology that they use will have an impact on overall student learning and satisfaction.

Understanding teaching practices is a necessary first step towards their improvement. In the legal translation field, the object of this article, the need to revisit and challenge classroom practices is even more evident given the current impact of natural language processing technologies and the exponential increase in demand for multilingual content. Thus, even if legal translation is one of the translation fields which is growing most steadily, the potential impact of automation is giving rise to a subtle, yet steady, shift in its traditional niche. Hence the need to assess the way legal translation is not only performed but also learnt and taught. 
This article delves into the teaching resources and strategies used by legal translation lecturers in Spain, connecting the classroom practice of said lectures to different teaching and learning styles. In the second part of this article, we will analyze the results obtained through a questionnaire distributed among legal translation lecturers and examine the teaching resources and strategies that, to this day, seem to prevail in legal translation education at undergraduate level in Spain. The findings obtained will provide a mapping of how legal translation education is performed in the country, which can become a good starting point to discuss how legal translation education should adapt to the abovementioned challenges posed by automation.

\section{Defining Effective Teaching in the EHEA Landscape}

The 2018 ministerial meeting of the EHEA, held in Paris, speaks of the "full" implementation of student-centered learning and the need to "promote and support institutional, national and European initiatives for pedagogical training and continuous professional development of higher education teachers" while exploring "ways for better recognition of high quality and innovative teaching in their career" (EHEA Ministerial Conference, 2018, p. 4).

From this statement, two questions emerge. Firstly, there is awareness within the EHEA that the key to effect the educational change promoted at institutional level is based on the pedagogical training of educators and better recognition of high-quality teaching. The second question is the pedagogical model that it promotes, framed within participatory teaching philosophies and based on a situated view of education as a product of the individual's interaction with both other individuals and the environment. The long-held teaching perspectives based on a one-size-fits-all notion of curriculum and good teaching seem to have given way to more context-dependent approaches. In contrast, the EHEA now seeks active engagement on the part of the student, accountability and responsibility in their learning process, and a reflective approach to both the teaching and learning process (Jorgensen et al., 2018, p. 194).

However, the data from the 2015 PISA report (Programme for International Student Assessment), although applied to secondary school teaching, highlights the positive association between teacher-directed instruction and student performance, and considers whether it is once again necessary to reinforce teacher-directed instruction in pre-university teaching (Álvarez Morán et al., 2018, p. 85). Although some authors have called for caution in the handling of causal inferences that could be deduced from PISA reports (Fernández-Cano, 2016, as cited by Postareff, Lindblom-Ylänne and Nevgi (2007, p. 2), "teaching and learning are not two distinct phenomena." Consequently, there are numerous existing studies that connect teaching styles to productivity, performance, and student success.

Even though the relationship between effective teaching and student performance is difficult to measure because of the great number of variables at play (psychological, physiological, socioeconomics, etc.), Gargallo et al. $(2011,2018)$ and Aguilera (2012) claim that there is a meaningful influence of the teaching method on the way students learn. They conclude that, when the teacher makes use of student-centered methodologies, students develop better-quality learning strategies, better attitudes and a deeper approach to learning.

\section{Effective Teaching \& Strategic Excellence}

Literature on teacher effectiveness has traditionally centered around identifying effective practices and behaviors of teachers in relation to concrete variables in the teaching-learning process (student engagement in the classroom, student motivation and self-efficacy, etc.). However, it has been claimed that, in general, it lacks an understanding of how effective teaching develops (van der Lans et al., 2018, p. 247). 
Generally, effective teaching is considered from a complex perspective that combines three different dimensions: the instructional dimension, related to the cognitive engagement of students and their meaningful learning; the organizational dimension, related to successful classroom management; and the emotional dimension, which grants students the learning support they need in the form of supportive learning environments and positive student-lecturer relationships (Holzberger et al., 2019).

That being said, it remains unknown which mechanisms motivate lecturers to combine these key teaching quality variables simultaneously, or to prioritize certain variables over others, and how many of these dimensions should be set in motion at the same time for teaching to be considered effective (Spooren et al., 2013). Nie and Lau (2009), for instance, suggest that this might be attributable to individual differences in lecturers' self-concept, insofar as, for example, those who see themselves principally as educators accentuate the emotional dimension of education.

Many existing studies examine the specific dimensions of effective teaching. Fuller (1969), for example, offers one of the first classifications of those teaching behaviors that characterize effective teaching, although his study is based on analyzing trends in teachers' self-reported concerns and thus his conclusions are based on non-behavioral concepts that cannot be observed directly in the classroom. More recently, Buskist et al. (2002) propose a list of 28 qualities and their related behaviors known as the Teacher Behaviour Checklist, modified years later to be adapted to the Likert format (Keeley et al., 2006). Through interviews and classroom recordings, Bain (2004) identifies seven common principles that characterize effective teaching in university environments. Feldman $(1996 ; 2007)$, through a study of students' evaluation of a course, aims to find which of the 28 dimensions of instruction that he identifies have a higher incidence in student learning (Feldman, 2007, pp. 103-104).
While the aim of virtually all studies is to examine what happens in the classroom, Gargallo et al. (2011, pp. 16-17) or Gurung et al. (2018, pp. 13-15) delve into the performance and interaction inside and outside the classroom, lesson planning, and assessment to examine the multidimensional aspects of high-quality teaching. In the development of their Model Teaching Criteria (Boysen et al., 2015), Gurung et al. (2018) identify the following dimensions associated with effective teaching:

- Training. Effective teachers are trained, whether through formal training or self-training, not only in their area of specialization but also in pedagogical theory and practice.

- Syllabi. Effective teachers employ learnercentered principles to design their syllabi and, in this way, define relationships with their students, providing a cognitive map and learning tool for the course. Effective teachers make the necessary changes to their syllabi every semester according to student feedback and include a clear description of how the learning objectives are connected to each assignment and assessment within the course.

- Instructional methods. Effective teachers employ many different instructional methods depending on the situation.

- Course content. In addition to the specific competences relevant to their subject, effective teachers exercise communication, critical thinking, and collaborative skills "through creative assessments, class activities, assignments, and syllabi that engender disciplinary guidelines" (Gurung et al., 2018, p. 15).

- Assessment process. Effective teachers focus on the evaluation of student learning, making efforts to clearly define their learning goals, "assessing student learning outcomes, and providing direct and useful feedback to students" in the form of constructive feedback 
(both summative and formative; Gurung et al., 2018, p. 15).

- Student Evaluations of Teaching. Effective teachers "use student evaluations of teaching to reflect on and improve their practice" (Gurung et al., 2018, p. 15).

\section{Method}

The goal of this study was to examine how different dimensions of effective teaching were organized among legal translation lecturers in Spain and how their greater or lesser preference for student-centered teaching approaches correlated with their teaching abilities with regards to lesson planning, interaction with students inside and outside the classroom and assessment practices. In particular, the study explored whether lecturers who display student-centered learning environments implemented more teaching strategies in their classroom compared to those lecturers who leaned towards teacher-centered environments.

\section{Participants}

For the study, the population of legal translation lecturers in Spain who teach at the undergraduate level was contacted, as this population was countable, well-defined and relatively accessible. At first, it undertook to analyze the syllabi in the legal translation subjects obtained from the university websites offering programs in translation and interpreting at the undergraduate level in Spain. From this information, a census was designed, containing information on the following areas: name of the undergraduate degree program, name of the university, name of the module, number of credits, name(s) of the lecturer(s), academic position of the lecturer, and e-mail address of the lecturer.

At the first stage of the census, 112 modules in legal translation and 118 lecturers were included. Even if most degrees in translation and interpreting in Spain have clearly defined legal translation modules, in some cases (University of València, University of Granada), following the recommendations of the White Paper on the Degrees in Translation and Interpreting in Spain (Muñoz Raya, 2004), their curriculum have more generalist areas of specialized translation where issues related to legal translation, technical translation, and scientific translation are combined. For those cases lecturers were contacted by email to see whether they taught the legal translation part of those specialized translation modules or not. Those who did not (11 lecturers in total) were discarded. In total, 107 lecturers in legal translation were contacted, of whom 80 (71.4\%) played an active part in the data collection process. Table 1 lists the sociodemographic profile of the lecturers in question. As can be observed, the profile of legal translation lecturers in Spain is composed predominantly of women (67.5\%).

Concerning the age of those lecturers, the average respondent was 44.26 years old $(\mathrm{SD}=9.6)$. Around $84 \%$ of those who answered the questionnaire were located in the $36+$ age bracket. In relation to teaching experience, the respondents claimed to have spent an average of 15 years $(\mathrm{SD}=9.43)$ lecturing at university. Regarding the academic position they hold, different types of full-time, permanent positions were the most common option (profesor titular: 26\%; profesor contratado doctor: 19\%; catedrático: $5 \%),{ }^{1}$ followed by part-time, non-academic lecturers (profesor asociado: $28 \%$ ). Finally, concerning the legal education that those lecturers had received, $24 \%$ of the respondents claimed that they had not received any kind of law-related course or seminar; while, at the other end of the spectrum, 13\% claimed to hold a master's degree in Law and 10\% of them claimed to hold an undergraduate degree in Law. The most common option was that of

1 Both profesor contratado doctor and profesor titular would be associate professors in Anglophone countries. In Spain, both positions have a similar status; the only difference being that a profesor titular is a civil servant. 
Table 1 Socio-demographic profile of the legal translation faculty in Spain

\begin{tabular}{ll}
\hline Sex & \\
Women & $67.5 \%(n=55)$ \\
Men & $30 \%(n=25)$ \\
\hline Age & $\bar{X}=44.26 ; 5 d=9.64$ \\
$<35$ & $16.3 \%(n=13)$ \\
$36-44$ & $41.3 \%(n=33)$ \\
$>45$ & $42.5 \%(n=34)$ \\
\hline Academic position & \\
Profesor asociado & $28 \%(n=22)$ \\
Profesor titular & $26 \%(n=21)$ \\
Profesor contratado doctor & $24 \%(n=19)$ \\
Profesor colaborador & $9 \%(n=7)$ \\
Catedrático & $5 \%(n=4)$ \\
Profesor ayudante doctor & $4 \%(n=3)$ \\
Lecturer at private university & $4 \%(n=3)$ \\
Ph. D. student & $1 \%(n=1)$ \\
\hline Legal background & \\
Courses and seminars & $48 \%(n=38)$ \\
No & $24 \%(n=19)$ \\
Non-formal education & $21 \%(n=17)$ \\
Master's degree & $13 \%(n=10)$ \\
Bachelor's degree & $10 \%(n=8)$ \\
\hline Active years in the field & $8 \%(n=6)$ \\
\hline Note: Equivalent rate degree & \\
\hline
\end{tabular}

Note: Equivalent ranks are as follows: Profesor asociado: Parttime position, Ph. D. not required; Profesor titular: Tenured position, full time, civil servant, $\mathrm{Ph}$. $\mathrm{D}$. required, accreditation required; Profesor contratado doctor: Tenured position, full time, not a civil servant, $\mathrm{Ph}$. D. required, accreditation required; Profesor colaborador: Tenured position, Ph. D. not required, accreditation required; Catedrático: Tenured position, full time, civil servant, $\mathrm{Ph}$. D. required, accreditation required; Profesor ayudante doctor: Non-Tenured position, full time, not a civil servant, $\mathrm{Ph}$. D. required, accreditation required.

complementary, specific, law-related courses and seminars, coupled with other non-formal education initiatives (69\% in total, altogether).

\section{The TAMUfQ Questionnaire}

The choice was made to use the questionnaire proposed by Gargallo et al. (2011), entitled TAMUFQ
(Teaching and Assessment Methodology of University Faculty Questionnaire). The questionnaire evaluates the teaching and assessment methodology of university lecturers and includes the benchmarks from the original comprehensive study conducted in Spain with lecturers in all disciplines and areas of knowledge. This means that the results for one particular cohort, such as our legal translation lecturers, can be located in relation to the percentile scores from the overall results, giving the data collected a new comparative dimension.

Other similar questionnaires were taken into consideration (García Ramos, 1998; Marsh, 1987), but they were discarded since they were not addressed to lecturers, which was our main goal in this study. Besides, TAMUFQ assesses not only classroom strategies, as we will see below, but also beliefs and behaviors of lecturers, which was a key piece in the study, aimed at linking certain learning environments to particular classroom strategies. The questionnaire is comprised of three complementary scales in the Likert format. The first two scales (item 1 to 31 ) are focused on situating the lecturer within student-centered or teacher-centered classroom models, while the third scale (items 32-51) examines the different instructional dimensions which, as seen above, have been linked to effective teaching.

The initial results based on the first two scales (Martínez-Carrasco, 2021) confirm that legal translation lecturers in Spain are generally aligned with the EHEA's objectives with respect to studentcentered pedagogy. However, in practice, they adopt hybrid models which incorporate elements of both the student-centered and the teacher-centered approach (i.e., in negotiation of the syllabus, content, and assessment). The conceptual weight of law in legal translation subjects seems to justify, to some extent, that the lecturer adopts a traditional role as a transmitter of knowledge, although in practical translation workshops they do adopt a rather scaffolding role. The study confirmed, in line with other similar investigations 
(González-Peiteado \& Pino-Juste, 2016, p. 1187), that female lecturers tend to employ a more student-centered approach in the classroom when compared to their male colleagues.

With regards to the third scale, upon which this study focuses, it is structured around the following five factors: planning skills, instructional skills, interactional skills, and assessment skills, related to well-defined, objective-based assessment and the use of initial, formative, and continuous assessment. The corresponding items from scale 3 are listed in Appendix 1.

\section{Data analysis}

SPSS v.18.0 (IBM Corp., Armonk, NY, USA) was used for the descriptive and differential analysis of responses, in order to examine the nature and characteristics of the teaching practice of legal translation lecturers in Spain. After analyzing the results and the classroom behaviors reported by legal translation lecturers, it was decided to explore whether the lecturers who adopted a student-centered approach are more inclined to incorporate teaching strategies in their lecturing that have been linked to effective teaching to a statistically significant extent. In order to do that a bivariate analysis (Pearson's correlation coefficient) was performed on the data.

It is worth noting that every participant in the study was duly informed about it and agreed to participate in it. The author complied with all the applicable legal obligations regarding data collection and protection. Individual replies and comments were anonymized.

\section{Results}

The following section presents the results of the study. Firstly, a descriptive analysis of the items regarding the different classroom strategies and resources implemented by lecturers is performed. The analysis is followed by a bivariate analysis aimed at comparing those answers with the position of lectures in the positivist/post-positivist pedagogical spectrum (Scale $1 \&$ Scale 2 of the questionnaire).

\section{Effective Teaching Strategies and Behaviors in the Legal Translation Classroom}

Table 2 shows the results obtained in the third scale of the questionnaire, in relation to effective teaching and teaching strategies and behaviors in the classroom.

With an overall result of $\bar{x}=4.50(\mathrm{SD}=.39)$, legal translation lecturers in Spain confirm that, in the classroom, they incorporate a variety of strategies and resources associated with effective teaching. In fact, the majority of items have no results on the lower end of the scale, with a few exceptions of little significance beyond item 48 , which will subsequently be analyzed.

The first of these factors, S3F1 ( $\bar{x}=4.74$; $\mathrm{SD}=.37)$, is related to lesson planning and course design. According to the respondents' replies, the majority of them adjust their syllabi on a yearly basis in relation to the group's needs based on feedback received from students (Item 32: $\bar{X}=4.60$; $\mathrm{SD}=.54)$. Furthermore, lecturers set clear, reasonable objectives for each of their courses (Item 34: $\overline{\mathrm{X}}=4.89 ; \mathrm{SD}=.32$ ), a statement with which $89 \%$ of respondents "completely agree," and the remaining $11 \%$ "agree."

Moreover, lecturers seem to go through the syllabus with their students in the classroom, explaining and clarifying any issues connected to content, methodology, assessment methods, and bibliography for the module (Item 33: $\overline{\mathrm{X}}=4.84$; $\mathrm{SD}=.37$ and Item $35: \overline{\mathrm{X}}=4.63 ; \mathrm{SD}=.79)$. It is significant, in this factor, that the only negative response found is precisely in item 35 ("My students know the essential bibliography for the course"), where $3 \%$ of lecturers, despite their efforts for students to know the syllabus, are not convinced that students know the essential bibliography for the subject. 
Table 2 Teaching Strategies (TAmufQ Scale 3 Results)

\begin{tabular}{|c|c|c|c|c|c|c|c|c|c|c|}
\hline & $\mathbf{N}$ & Min & Max & Mean & SD & 1 & 2 & 3 & 4 & 5 \\
\hline Item 32 & 80 & 3 & 5 & 4.60 & .54 & - & - & $3 \%$ & $35 \%$ & $63 \%$ \\
\hline Item 33 & 80 & 4 & 5 & 4.84 & .37 & - & - & - & $16 \%$ & $85 \%$ \\
\hline Item 34 & 80 & 4 & 5 & 4.89 & .32 & - & - & - & $11 \%$ & $89 \%$ \\
\hline Item 35 & 80 & 1 & 5 & 4.63 & .79 & $3 \%$ & - & $4 \%$ & $20 \%$ & $74 \%$ \\
\hline Item 36 & 80 & 3 & 5 & 4.68 & .50 & - & - & $1 \%$ & $30 \%$ & $69 \%$ \\
\hline Item 37 & 80 & 2 & 5 & 4.40 & .85 & - & $4 \%$ & $13 \%$ & $24 \%$ & $60 \%$ \\
\hline Item 38 & 80 & 1 & 5 & 4.40 & .87 & $1 \%$ & $3 \%$ & $10 \%$ & $28 \%$ & $59 \%$ \\
\hline Item 39 & 80 & 1 & 5 & 4.38 & .91 & $1 \%$ & $4 \%$ & $10 \%$ & $26 \%$ & $59 \%$ \\
\hline Item $\mathbf{4 0}$ & 80 & 1 & 5 & 3.86 & 1.06 & $1 \%$ & $11 \%$ & $33 \%$ & $30 \%$ & $35 \%$ \\
\hline Item 41 & 80 & 1 & 5 & 4.75 & .59 & $1 \%$ & - & - & $20 \%$ & $79 \%$ \\
\hline Item 42 & 80 & 3 & 5 & 4.81 & .42 & - & - & $1 \%$ & $16 \%$ & $83 \%$ \\
\hline Item 43 & 80 & 3 & 5 & 4.64 & .60 & - & - & $6 \%$ & $24 \%$ & $70 \%$ \\
\hline Item 44 & 80 & 3 & 5 & 4.54 & .64 & - & - & $8 \%$ & $31 \%$ & $61 \%$ \\
\hline Item 45 & 80 & 3 & 5 & 4.70 & .58 & - & - & $6 \%$ & $18 \%$ & $76 \%$ \\
\hline Item 46 & 80 & 3 & 5 & 4.81 & .42 & - & - & $1 \%$ & $16 \%$ & $83 \%$ \\
\hline Item 47 & 80 & 3 & 5 & 4.69 & .59 & - & - & $6 \%$ & $19 \%$ & $75 \%$ \\
\hline Item 48 & 80 & 1 & 5 & 3.04 & 1.47 & $23 \%$ & $15 \%$ & $21 \%$ & $19 \%$ & $23 \%$ \\
\hline Item 49 & 80 & 1 & 5 & 4.33 & .99 & $4 \%$ & $1 \%$ & $11 \%$ & $26 \%$ & $58 \%$ \\
\hline Item 50 & 80 & 1 & 5 & 4.29 & .96 & $3 \%$ & $3 \%$ & $13 \%$ & $29 \%$ & $54 \%$ \\
\hline Item 51 & 80 & 3 & 5 & 4.73 & .48 & - & - & $1 \%$ & $25 \%$ & $74 \%$ \\
\hline S3F 1 & 80 & 3.50 & 5 & 4.74 & .37 & - & - & - & - & - \\
\hline S3F2 & 80 & 2.40 & 5 & 4.34 & .64 & - & - & - & - & - \\
\hline S3F3 & 80 & 3.67 & 5 & 4.73 & .41 & - & - & - & - & - \\
\hline S3F4 & 80 & 3.50 & 5 & 4.68 & .43 & - & - & - & - & - \\
\hline S3F5 & 80 & 2.25 & 5 & 4.09 & .71 & - & - & - & - & - \\
\hline S3 & 80 & 3.40 & 5 & 4.50 & .39 & - & - & - & - & - \\
\hline
\end{tabular}

The second factor, S3F2, addresses issues related to classroom management. Data shows how the contents of the respondents' module are based on the objectives and learning outcomes established at the beginning of the course, according to criteria of relevance, applicability and student interest (Item 36: $\bar{x}=4.68$; SD $=.50) .99 \%$ of participant lecturers agree with this statement $(69 \%$ "completely agree" and 30\% "agree"). According to the lecturers, students know the objectives of each of the classroom sessions (Item 38: $\bar{X}=4.40$; $\mathrm{SD}=.87)$ and are continually reminded of how the contents of the course link together, creating a central thread throughout the semester (Item 39: $\overline{\mathrm{X}}=4.8 ; \mathrm{SD}=.91)$. Slightly less frequent, yet still important among the lecturers surveyed (Item 40:
$\overline{\mathrm{X}}=3.86 ; \mathrm{SD}=1.06)$ is the fact that students are presented with a short "wrap up" summary at the end of sessions, providing coherency and situating the session within the corresponding module.

The third factor, S3F3, displays the highest score in the entire scale $(\overline{\mathrm{X}}=4.73 ; \mathrm{SD}=.41)$. It is related to the emotional dimension of education, personal commitment on the part of lecturers, and their involvement in the personal development of students. Here, $99 \%$ of respondents replied that they "agree" (16\%) or "completely agree" (83\%) with a willingness to create a good environment for interpersonal relationships in the classroom (Item 42: $\bar{x}=4.81 ; S D=.42$ ), seeking to convey their interest for the subject to their students 
(Item 41: $\overline{\mathrm{X}}=4.75 ; \mathrm{SD}=.59$ ). Consequently, 94\% say they have concern for their students as human beings and not only as learners (Item 43: $\overline{\mathrm{X}}=4.64$; $\mathrm{SD}=.60)$.

Assessment related issues are addressed in factor S3F4 $(\overline{\mathrm{X}}=4.68 ; \mathrm{SD}=.43)$ and in factor S3F5 $(\overline{\mathrm{X}}=4.09 ; \mathrm{SD}=.71)$, the latter showing the lowest results on the entire scale. In general, lecturers acknowledge that their students are familiar not only with their marking criteria (Item 47: $\overline{\mathrm{X}}=4.69 ; \mathrm{SD}=.57)$ but also with the overall assessment criteria of the module (Item 45: $\bar{X}=4.70$; $\mathrm{SD}=.58)$, both of which are in line with the objectives of the course (Item 44: $\overline{\mathrm{X}}=4.54 ;=.64$ ). Assessments are carried out over the duration of the term instead of one final assessment (Item 49: $\bar{X}=4.33 ; S D=.99$ ), and their outcomes are used, to a certain degree, to review and modify — when necessary-the syllabus and the lecturer's lesson planning or methodology, both in the short or long term (Item 50: $\overline{\mathrm{X}}=4.29 ; \mathrm{SD}=.96)$. Item 48 $(\bar{X}=3.04 ; \mathrm{SD}=1.47)$ is significant for having the lowest level of acceptance. It deals with the use of initial or diagnostic assessments developed to obtain information on students' prior knowledge and therefore select the most suitable methodology for each and every group. As seen in Table 2 above, there is no clear response pattern: While $23 \%$ of lectures claim to have no initial diagnostic testing in their module, another $23 \%$ express clear support for them (and $21 \%$ have no strong opinion on the subject).

\section{The Relationship Between Effective Teaching Strategies and Student-Centered Approaches}

Table 3 explores the relationship between both variables through a bivariate analysis undertaken among the factors that comprise Scale 3 of the questionnaire, the results of which have been analyzed above, with the factor and scale results of Scale 2, relating to student-centered teaching styles. The overall results of Scale 1, that is, the teacher-centered approaches, are also included as a variable of reference (Martínez-Carrasco, 2021).

As can be observed, there is a strong relationship between Scale 2 and Scale 3 both on a global level

Table 3 Pearson's correlation coefficient

\begin{tabular}{|c|c|c|c|c|c|c|c|c|c|c|c|c|}
\hline & $\mathrm{S} 2 \mathrm{Fl}$ & S2F2 & S2F3 & S2F4 & S3F 1 & S3F2 & S3F3 & S3F4 & S3F5 & s1 & S2 & S3 \\
\hline S2F 1 & 1 & $.31^{* *}$ & $.40^{* * *}$ & $.62^{* * *}$ & $.41^{* *}$ & $.58^{* * *}$ & $.39^{* * *}$ & $.42^{* *}$ & $.36 * *$ & .11 & $.81^{* *}$ & $.59^{* *}$ \\
\hline S2F2 & & 1 & .15 & $.23^{*}$ & .091 & .21 & $.29 *$ & .21 & .17 & .02 & $.53^{* *}$ & $.25^{*}$ \\
\hline S2F3 & & & 1 & $.51^{* * *}$ & .21 & $.39^{* * *}$ & $.30^{* * *}$ & $.23^{*}$ & $.47^{* *}$ & .12 & $.77^{* *}$ & $.46^{* * *}$ \\
\hline S2F4 & & & & 1 & $.43^{* *}$ & $.54^{* * *}$ & $.38^{* * *}$ & $.53^{* *}$ & $.48^{* * *}$ & .07 & $.77^{* *}$ & $.64^{* * *}$ \\
\hline S3F 1 & & & & & 1 & $.32 * *$ & $.42^{* *}$ & $.56^{* *}$ & $.33^{* *}$ & .09 & $.38 * *$ & $.62^{* * *}$ \\
\hline S3F2 & & & & & & 1 & $.43^{* * *}$ & $.52 * *$ & $.50^{* * *}$ & .12 & $.59^{* * *}$ & $.82^{* *}$ \\
\hline S3F3 & & & & & & & 1 & $.46^{* *}$ & $.42 * *$ & .15 & $.46^{* * *}$ & $.66^{* *}$ \\
\hline S3F4 & & & & & & & & 1 & $.47^{* *}$ & .08 & $.45^{* *}$ & $.77^{* * *}$ \\
\hline S3F5 & & & & & & & & & 1 & .22 & $.51^{* *}$ & $.79^{* * *}$ \\
\hline S1 & & & & & & & & & & 1 & .08 & .15 \\
\hline S2 & & & & & & & & & & & 1 & $.66^{* *}$ \\
\hline S3 & & & & & & & & & & & & 1 \\
\hline
\end{tabular}

${ }^{*}$ Level of significance $\mathrm{p} \leq 0.05$

${ }^{* *}$ Level of significance $\mathrm{p} \leq 0.001$ 
and in the factors from which it is composed. In a consistent manner, during the analysis of data, those lecturers who adopt student-centered approaches in their classroom also display a wider range of strategies related to planning, classroom methodology, and assessment. At the same time, lecturers with a teacher-centered, transmissionist approach to education did not obtain significant results in Scale 3, the one indicating the use of strategies commonly linked to effective teacher behavior.

This occurs when the interrelation between the first and the third scale is analyzed as a whole (S1 $\& S 3 ; \mathrm{r}=.15 ; \mathrm{p}=.191)$ and also at individual level within each one of the factors that comprise it.

However, the strong statistical relationship between Scale 2 and Scale 3 (S2 \& S3; r = .66; $\mathrm{p} \leq 0.001$ ) is in fact translated to practically every factor, which seems to indicate a solid relationship between postpositivist approaches adopted by teachers in higher education (Kiraly \& Hofmann, 2016) and a classroom practice considered to be more effective. At the organizational level, lecturers who assume student-centered approaches have a greater tendency to plan their subject year by year, and to take time to explain the syllabus to their students, clarifying the course objectives and the essential bibliography that they need to consult in order to pass the module (S2 \& S3F1; r = .38; $\mathrm{p} \leq 0.001)$.

With regards to student assessment, the correlation is equally strong. Lecturers who undertake to scaffold their student learning process are statistically more likely to communicate the learning outcomes and evaluation methods of their syllabi (S2 \& S3F4; $\mathrm{r}=.45 ; \mathrm{p} \leq 0.001)$, to apply diagnostic testing and formative assessment criteria in classes, and to consider the assessment of the course as a means of improving it for future courses (S2 \& $\mathrm{S} 3 \mathrm{~F} 5 ; \mathrm{r}=.51 ; \mathrm{p} \leq 0.001)$.

As for the emotional dimension, lecturers adopting post-positivist approaches share a common willingness to stimulate interest in the discipline among the students, cultivating an atmosphere that encourages interpersonal relationships both inside and outside the classroom, showing a greater interest in the development of their students as human beings (S2 \& S3F3; $\mathrm{r}=.46 ; \mathrm{p} \leq 0.001$ ).

\section{Discussion and Conclusions}

This article emphasizes how the progressive demand for better accountability of the structures that govern, manage, and plan higher education has brought to light the need to substantiate the quality of teaching, among other aspects. To this end, different positions in relation to teaching styles have been analyzed because, despite the fact that relevant literature seems to favor studentcentered approaches, we cannot forget the double etymological root of the word "educate": on one hand, educere, that is, the capacity of the student to enhance their learning; on the other hand, $e d u$ care, to feed, or to fill someone with knowledge.

Teaching effectiveness has been characterized as a complex, multidimensional concept that comprises an instructional dimension, an organizational dimension, and an emotional dimension (Holzberger et al., 2019) that are combined and reorganized to give rise, through the conjunction of certain teaching strategies and behaviors, to an emergent dialogic activity in constant flux, context-dependent, and culture-dependent, which cannot be reduced to the sum of the actual teaching behaviors set in motion. A number of variables has been identified and analyzed in relation to performance and interaction, as well as lesson planning and assessment, and these have been applied in order to analyze the behavior of a set of legal translation lecturers in Spain.

Theresultshaverevealedhighscoreson thepartoflecturers in each of the three dimensions that have been associated with effective teaching (instructional, organizational, emotional), wherein the majority of responses have systematically reached the highest values on the scale. The only exception seems to be initial diagnostic testing, the only item analyzed in which the response rate is distributed 
equally across the spectrum. Furthermore, results demonstrate how lecturers who adopt a studentcentered approach, to a statistically significant degree, tend towards the use of a greater number of strategies and teaching resources, while lecturers with a transmissionist profile do not show the same incidence.

One of the reasons for the high level of ascription among the surveyed lecturers to strategies associated with post-positive approaches could be the fact that translation, as an academic discipline, is more closely linked to practice - to procedural knowledge - than many other more long-standing disciplines. Thus, a priori, this makes it more natural and seamless to incorporate varied strategies and resources into the classroom, that is, to mobilize the declarative, procedural, and attitudinal dimensions of translation competence. We must not forget that we are also talking about a younger discipline, less affected by the weight of tradition when it comes to its pedagogy.

Of course, it may be the case that lecturers who participated in the study fabricated their results according to what they thought the researcher expected. A quantitative analysis of this type admittedly runs the risk of being slightly distorted in terms of the honesty of the answers received. Clearly, the ideal would be to complement and triangulate the results with other parallel techniques of data collection, including, for example, direct observation in the classroom and student perceptions of the lecturer's teaching practice (Bain, 2004). With regards to the first, the presence of an external subject in the classroom would cause a certain deviation of a standard class and would not allow for the evaluation of aspects of effective teaching that are outside the margins of classroom interaction (lesson preparation, etc.) as well as more emotional aspects (i.e., teaching motivation). In the second case, although it has proved to be a reliable source of information in relation to teaching quality, the evaluation of effective teaching through student evaluations (Feldman, 2007;
Wagner et al., 2015) would be subject to the inevitable bias of those particular students.

As parallel lines of investigation that could arise from this study, there is the possibility of extending the sample population to all translation lecturers in Spain (irrespective of the particular subjects they teach) or to continue with legal translation lecturers, widening the sample to include all translation undergraduate degrees within the EHEA. The fact that the original study includes the scales obtained with a sample of Spanish university lecturers from a multitude of disciplines (Gargallo et al., 2011, pp. 30-31) makes it possible for a comparative study to be conducted, contrasting replies by those who teach translation and their colleagues in other faculties.

It would be interesting to examine how the dimensions that have been associated with effective teaching are interrelated within each of the different teaching styles and what factors motivate the teachers to prioritize some strategies over others in their professional practice. Starting from the assumption that there is not only one valid teaching style, and in line with Spooren et al. (2013) and Cohen (2015), more investigation is needed regarding the number of strategies and teaching behaviors that should be mobilized in order to provide students with quality teaching, and ultimately to design professional development programs for university lecturers aimed at the improvement of student learning processes.

\section{References}

Aguilera, E. (2012). Los estilos de enseñanza, una necesidad para la atención de los estilos de aprendizaje en la educación universitaria. Journal of Learning Styles, 5(10), 79-87.

Álvarez Morán, S., Carleos Artime, C., Corral Blanco, N., \& Prieto Rodríguez, E. (2018). Metodología docente y rendimiento en PISA 2015: Análisis crítico. Revista de Educación, (379), 85-113. https:// doi.org/10.4438/1988-592X-RE-2017-379-370

Bain, K. (2004). What the best college teachers do. Harvard University Press. https://doi.org/10.5465/ amle.2008.32712626 
Biesta, G. (2013). Interrupting the politics of learning. Power and Education, 5(1), 4-15. https://doi. org/10.2304/power.2013.5.1.4

Biesta, G. (2015). The duty to resist: Redefining the basics for today's schools. RoSE-Research on Steiner Education, $6,1-11$.

Boysen, G. A., Richmond, A. S., \& Gurung, R. A. R. (2015). Model teaching criteria for psychology: Initial documentation of teachers' self-reported competency. Scholarship of Teaching and Learning in Psychology, 1(1), 48-59. https://doi.org/10.1037/st10000023

Buskist, W., Sikorski, J., Buckley, T., \& Saville, B. K. (2002). Elements of master teaching. In S. Davis \& W. Buskist (Eds.), The teaching of Psychology: Essays in honor of Wilbert J. McKeachie and Charles L. Brewer (pp. 27-39). Mahwah, NJ: Lawrence Erlbaum. https:// doi.org/10.4324/9781410603586

Cohen, J. (2015). Challenges in identifying high-leverage practices. Teachers College Record, (117), 1-41.

Day, C. (2012). New lives of teachers. Teacher Education Quarterly, 39(1), 7-26.

De Courcy, E. (2015). Defining and measuring teaching excellence in higher education in the $21^{\text {st }}$ Century. College Quarterly, 18(1). http://collegequarterly. ca/2015-vol18-num01-winter/decourcy.html

Dorgu, T. E. (2015). Different teaching methods: A panacea for effective curriculum implementation in the classroom. International Journal of Secondary Education, 3(6-1), 77-87. https://doi.org/10.11648/j. ijsedu.s.2015030601.13

EHEA Ministerial Conference. (2018). Paris Communiqué. http://www.ehea2018.paris/Data/ElFinder/s2/Communique/EHEAParis2018-Communique-final.pdf

Feldman, K. (2007). Identifying exemplary teachers and teaching. In R. Perry \& J. Smart (Eds.), The scholarship of teaching and learning in higher education: An evidence-based perspective (pp. 93-143). Springer Netherlands. https://doi. org/10.1007/1-4020-5742-3

Feldman, K. A. (1996). Identifying exemplary teaching: Using data from course and teacher evaluations. New Directions for Teaching and Learning, (65), 41-50. https://doi.org/10.1002/tl.37219966509

Fuller, F. (1969). Concerns of teachers: A developmental conceptualization. American Educational Research Journal, (6), 207-226. https:// doi.org/10.3102/00028312006002207
García Ramos, J. M. (1998). Análisis de estructuras de covarianza en el estudio de la Competencia Docente del Profesor Universitario. Revista de Investigación Educativa, 16(1), 155-184.

Gargallo, B., Sahuquillo Mateo, P. , Verde, I., \& Almerich, G. (2018). What happens when teachers use learning-centered methods? Effects on learning approaches, on students' capacities and on their perception of learning environment. Revista de Educación, (382), 163-197. https://doi. org/10.4438/1988-592X-RE-2018-382-396

Gargallo, B., Suárez Rodríguez, J., Garfella Esteban, P. , \& Fernández March, A. (2011). El cuestionario CEMEDEPU. Un instrumento para la evaluación de la metodología docente y evaluativa de los profesores universitarios. Estudios Sobre Educacion, (21), 9-40.

González-Peiteado, M., \& Pino-Juste, M. (2016). Los estilos de enseñanza: construyendo puentes para transitar las diferencias individuales del alumnado. Revista Complutense de Educación, 27(3), 1175-1191. https://doi.org/10.5209/rev_RCED.2016.v27. n3.47563

Gurung, R. A. R., Richmond, A. S., \& Boysen, G. (2018). Studying excellence in teaching: The story so far. New Directions for Teaching and Learning, (156), 11-19. https://doi.org/10.1002/tl.20312

Holzberger, D., Praetorius, A.-K., Seidel, T., \& Kunter, M. (2019). Identifying effective teachers: The relation between teaching profiles and students' development in achievement and enjoyment. European Journal of Psychology of Education, 34, 801-823. https://doi. org/10.1007/s10212-018-00410-8

Jorgensen, M., Havel, A., Fichten, C., King, L., Marcil, E., Lussier, A., \& Budd, J. (2018). "Simply the best": Professors nominated by students for their exemplary technology practices in teaching. Education and Information Technologies, (23), 193-210. https:// doi.org/10.1007/s10639-017-9594-1

Keeley, J., Smith, D., \& Buskist, W. (2006). The teacher behavior checklist: Factor analysis of its utility for evaluating teaching. Teaching of Psychology, (33), 84-91. https://doi.org/https://doi.org/10.1207/ s15328023top3302_1

Kiraly, D., \& Hofmann, S. (2016). Towards a postpositivist curriculum development model for translator education. In D. Kiraly (Ed.), Towards authentic experiential learning in translator education (pp. 67-87). V\&R Press. https://doi. org/10.14220/9783737004954.67 
Marsh, H. W. (1987). Students evaluation of university teaching. Research findings, methodological issues and directions for future research. International Journal of Educational Research, 11(3), 255-388. https://doi.org/10.1016/0883-0355(87)90001-2

Martínez-Carrasco, R. (2017). Epistemological approaches to legal translation education: A situated account. Ph. D. Dissertation. Universitat Jaume I, Spain.

Martínez-Carrasco, R. (2021). Exploring the pedagogical beliefs of legal translation lecturers in Spain: Observations on classroom methodology and teaching philosophy. Innovaciones Metodológicas con TIC en Educación. Dykinson.

Muñoz Raya, E. (Ed.). (2004). Libro blanco. Título de Grado de Traducción e Interpretación. Euskal Herriko Unibertsitatea. https://www.ehu. eus/documents/1690128/1704927/libro_blanco_ Traduccion_Interpretacion_ANECA.pdf

Nie, Y., \& Lau, S. (2009). Complementary roles of care and behavioral control in classroom management: The self-determination theory perspective. Contemporary Educational Psychology, 34(3), 185-194. https://doi.org/10.1016/j.cedpsych.2009.03.001

Postareff, L., Lindblom-Ylänne, S., \& Nevgi, A. (2007). The effect of pedagogical training on teaching in higher education. Teaching and Teacher Education, 23(5), 557-571. https://doi.org/10.1016/j. tate.2006.11.013

Saroyan, A., \& Trigwell, K. (2015). Higher education teachers' professional learning: Process and outcome. Studies on Educational Evaluation, (46), 92-101. https://doi.org/10.1016/j.stueduc.2015.03.008

Spooren, P., Brockx, B., \& Mortelmans, D. (2013). On the validity of student evaluation of teaching: The state of the art. Review of Educational Research, (83), 598-642. https://doi.org/https://doi. org/10.3102/0034654313496870

Van der Lans, R., van de Grift, W., \& van Veen, K. (2018). Developing an instrument for teacher feedback: Using the Rasch Model to explore teachers' development of effective teaching strategies and behaviors. Journal of Experimental Education, 86(2), 247-264. https://doi.org/10.1080/00220 973.2016 .1268086

Wagner, W., Göllner, R., Werth, S., Voss, T., Schmitz, B., \& Trautwein, U. (2015). Student and teacher ratings of instructional quality: consistency of ratings over time, agreement, and predictive power. Journal of Educational Psychology, (118), 705-721. https:// doi.org/10.1037/edu0000075

How to cite this article: Martínez-Carrasco, R. (2021). Effective teaching strategies and behaviors of legal translation lecturers in Spain. Íkala, Revista de Lenguaje y Cultura, 26(2), 327-330. https://doi. org/10.17533/udea.ikala.v26n2a10 